\title{
THE EFFECTIVENESS OF NEST-BOX SUPPLEMENTATION FOR THE CONSERVATION OF EUROPEAN ROLLERS (CORACIAS GARRULUS)
}

\author{
Orsolya Kiss ${ }^{1}$, Béla Tokody ${ }^{2}$, Tünde Ludnai ${ }^{3}$ and Csaba Moská ${ }^{4}$ \\ ${ }^{1}$ Institute of Animal Sciences and Wildlife Management, University of Szeged \\ H-6800 Hódmezővásárhely, Andrássy út 15, Hungary; E-mail: orsolyakiss22@gmail.com \\ ${ }^{2}$ BirdLife Hungary, H-1121 Budapest, Költő u. 21, Hungary; E-mail: tokodyb@gmail.com \\ ${ }^{3}$ Kiskunság National Park Directorate \\ H-6000 Kecskemét, Liszt Ferenc utca 19, Hungary; E-mail: ludnait@knp.hu \\ ${ }^{4}$ MTA-ELTE-MTM Ecology Research Group, Biological Institute, Eötvös Lóránd University, \\ H-1117 Budapest, Pázmány Péter sétány 1/C, Hungary \\ $\mathcal{E}$ Hungarian Natural History Museum, H-1088 Budapest, Baross u. 13, Hungary; \\ E-mail:moskat@nhmus.hu
}

Provisioning of artificial nest-boxes proved to be an effective method to make suitable breeding sites for secondary cavity nester birds due to the lack of natural hollows. The European roller (Coracias garrulus) is a threatened bird species in Europe, which suffered a serious decline throughout its breeding range. Changing agricultural practices seem to be the main causes attributed to the shortage of suitable breeding sites. In this study we aimed to investigate which factors affect the occupancy rate of newly provided nest-boxes. Four-year rollers' occupancy data were analysed by generalized linear models. Our results showed that nest-box characteristics (holder type and height above ground) and the presence of conspecifics significantly influenced rollers' nest-box occupancy. We conclude that nest-box visibility, height and the presence of conspecifics should also be considered when starting a nest-box supplementation program to ensure an effective method for the conservation of rollers.

Keywords: nest-box, occupancy, conspecific presence, habitat, bird conservation

\section{INTRODUCTION}

In the last few decades, the populations of many farmland and grassland bird species have decreased in Europe (Donald et al. 2006). However, these bird species did not share the same habitat requirements, they can be classified to different groups, such as true grassland species or edge and forest species, which need bushy or forest habitat as breeding or perching site (VirkKala et al. 2004). Although several species, like the woodpeckers (Picidae), can excavate their own nesting holes in dead trees, forest management practices may selectively eliminate such trees, causing the scarcity of their 
optimal breeding places (MARTIN \& EAdIE 1999). Other cavity-nesting species occupy the abandoned hollows of woodpeckers, therefore their populations highly depend on the availability of these nesting holes, especially for species which need larger woodpecker hollows to breed. Good examples are stock doves (Columba oenas) and Tengmalm's owls (Aegolius funereus), which breed in the abandoned hollows of black woodpeckers (Dryocopus martius; JoHnsson et al. 1993). The decrease in the availability of nesting sites is one of the main factors responsible for the population decline in many cavity-nesting birds (SutHerland et al. 2004).

Preserving suitable habitats by maintaining proper management practices or restoring degraded habitats is probably the best method in bird conservation, however, it is not always feasible. Therefore, a simple and frequently applied method in conservation of cavity-nesting bird species is the supplementation of artificial nest-boxes. This method is efficient in the conservation of secondary cavity-nesters and may contribute to the increase of population size in threatened bird species (Newton 1994, Avilés \& Parejo 2004, Gottschalk et al. 2011, Olah et al. 2014). Although nest-box provisioning is typically helpful for bird conservation, it should be applied with caution, as nest-boxes in low-quality habitats may serve as ecological traps and make unsuitable sites attractive for birds with decreased reproductive success and increased mortality (KLeIN et al. 2007, Rodriguez et al. 2011). Providing artificial nesting places is usually labour-saving and costly, therefore conservation programmes need to evaluate their efficiency. To optimise conservation activity, several factors of nest-box design and their placement should be taken into consideration, as they may have various effects on breeding parameters (KorpimäKi 1985, Lowther 2012, Lambrechts et al. 2012, Møller et al. 2014). For example, several bird species show clear preference for a certain orientation of the holes of nest-boxes (Goodenough 2008, Navara et al. 2011, Rodriugez et al. 2011). The various components of habitats, such as vegetation structure and habitat composition (Avilés et al. 2000, Tome 2004, Remacha \& Delgado 2009, Lopez et al. 2010), may also play a role in nest site selection, influencing occupancy rate of artificial nest-boxes. Besides nest-box design and habitat characteristics, birds may use the presence/absence or breeding success of conspecifics and/or species with similar ecological requirements that provide valuable information on nest site suitability (DANCHIN et al. 2001, Pajero et al. 2004, WARd et al. 2004).

The European roller (Coracias garrulus) has undergone a serious population decline from the 1970's. It disappeared as a breeding species from Finland, Denmark, Germany and the Czech Republic (Cramp et al. 1998). A similar trend was also observed in the Hungarian population, as rollers disappeared from the western part of the country, and the stronger popula- 
tion of the eastern region also showed a serious decline (Magyar et al. 1998). Consequently, the European roller is enlisted in Annex 1 of European Union' Bird Directive and become a priority species in 2012. The international action plan for the species was elaborated in 2008 (Kovécs et al. 2008) to improve conservation measurements for rollers. Nowadays, roller populations show increasing trends in several countries, therefore its IUCN status was changed from Near Threatened (NT) to Least Concern (IUCN Red List Version 2015). The European roller has special habitat requirements; it is a secondary cavitynesting species and in the Carpathian Basin, mostly uses the abandoned hollows of green woodpeckers (Picus viridis) and black woodpeckers (SzIJj 1958). The method of nest-box supplementation for rollers proved to be successful in several countries, e.g. in Spain (Avilés \& SÁNChez 2000), Poland (SosNowski \& Chmielewski 1996), Austria (SACKl et al. 2004), and Hungary (Molnár 1998). Several aspects of this technique have already been revealed, such as the breeding parameters and potential threats (predation and decreased reproductive success) for rollers breeding in nest-boxes (Avilés et al. 2000, AviLÉs \& Pajero 2004, Sackl et al. 2004, Rodriguez et al. 2011).

In the present study our primary goal was to identify the factors affecting the occupancy rate of rollers in newly provided nest-boxes. We investigated the effects of nest-box characteristics (holder type, height above ground and orientation), the land-use cover at the territory scale and the presence of conspecifics on occupancy rate of nest-boxes. We aimed to determine which factors are primarily responsible for occupancy. We hypothesized that the presence and location of conspecifics may determine whether a nest-box is occupied by rollers or not. Furthermore, we studied which factors influence the frequency of occupancy of nest-boxes. We hypothesized that besides nestbox characteristics the higher coverage of suitable feeding sites may promote the re-occupancy of newly established nesting sites.

\section{METHODS}

\section{Study area and nest box installation}

The study was conducted in southern Hungary in two neighbouring counties, Csongrád (total area: $4262.68 \mathrm{~km}^{2}, \mathrm{~N}^{\circ} 6^{\circ} 25^{\prime} 35.25^{\prime \prime}$; E20 $14^{\prime}$ 05.75") and Bács-Kiskun (total area: $8445.15 \mathrm{~km}^{2}, \mathrm{~N} 46^{\circ} 34^{\prime} 01.59^{\prime \prime} ; \mathrm{E} 19^{\circ} 22^{\prime} 42.17^{\prime \prime}$ (WGS 84)). The number of already installed nest-boxes was 299 in Csongrád county (mean distance: $548 \mathrm{~m} \pm 728$ s.d.) and 63 in BácsKiskun county (mean distance: $1548 \mathrm{~m} \pm 4695$ s.d.). This area is considered to have a core population of rollers in Hungary, although it also suffered from a significant decline of Rollers in Hungary in the 1970s and 1980s (Haraszthy 1984). The nest-box installation program began in southern Hungary in 1988. The estimated number of roller pairs based on territory mapping and nest-box checking was 407 in 2010, and 52\% of them used artificial nest-boxes (Kiss \& Tокору 2010). Nest-boxes involved in this study were installed in new 
sites (68 in Csongrád and 64 in Bács-Kiskun counties) between the autumn of 2010 and early spring of 2011, within the frame of a conservation management program by local amateur ornithologists of BirdLife Hungary. All new nest-boxes were available for rollers during the breeding season of 2011.

\section{Nest-box parameters and occupancy}

The nest-box design was the same in all cases of the newly installed boxes (dimensions: $40 \mathrm{~cm} \times 30 \mathrm{~cm} \times 25 \mathrm{~cm}$; Fig. 1). The following parameters of the boxes were recorded in the field after installation: orientation of entrance ("orientation"; N, NE, E, SE, S, SW, $\mathrm{W}$, and NW), height above ground (m) and holder type (pylon or tree). We compiled occupancy records in nest boxes between 2011 and 2014. We considered a nest-box occupied by rollers if eggs or nestlings were present. We also registered any signs of nest failures. When adult rollers were regularly observed defending their nest-boxes, these were considered as nesting attempts. The occupancy of nest-boxes was checked at least once during June or July.

\section{Landscape composition, nearest neighbour and density}

We measured the components of landscape composition, the distance to nearest neighbour and calculated rollers' density. The land-use cover was measured around the nest-boxes in a circular plot with a $1 \mathrm{~km}$ radius. Rollers use this range most frequently as published observations suggest (Cramp et al. 1993, Molnár 1998, Avilés \& Parejo 2004). Data on land-cover composition were extracted from the maps of the CORINE 50 Land
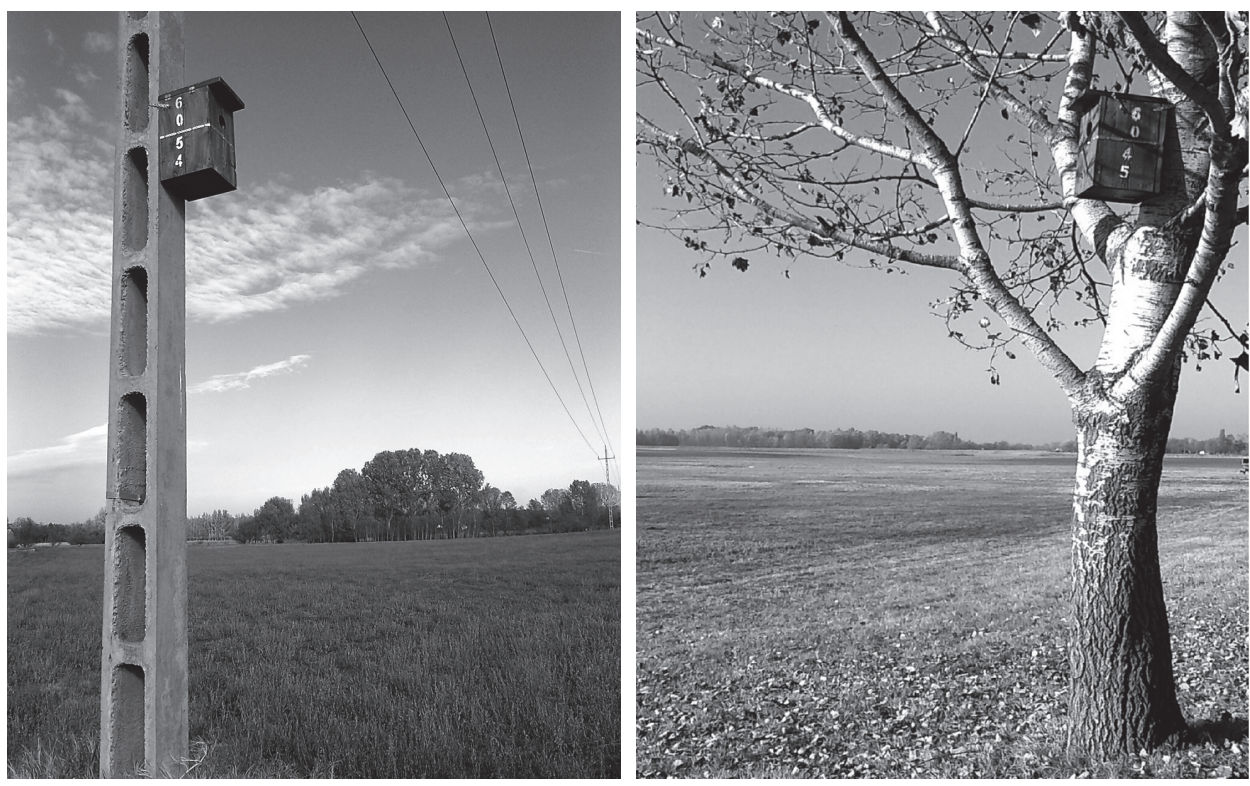

Fig. 1. Artificial nest-boxes placed on pylon $($ left $=a)$ and in tree (right $=b)$ 
Table 1. Description and descriptive statistics (mean and se) of explanatory variables.

\begin{tabular}{|c|c|c|}
\hline Variable (short name) & Description & $\begin{array}{c}\text { Mean } \pm \text { SD } \\
\text { (in scale variables) }\end{array}$ \\
\hline Orientation & $\begin{array}{l}\text { Orientation of nest-box en- } \\
\text { trance }\end{array}$ & $\begin{array}{c}\mathrm{N}(8.3 \%), \mathrm{NE}(9.1 \%), \mathrm{E}(13.6 \%), \\
\mathrm{SE}(15.2 \%), \mathrm{S}(14.4 \%), \mathrm{SW} \\
(7.6 \%), \mathrm{W}(16.6 \%), \mathrm{NW}(15.2 \%)\end{array}$ \\
\hline Height & Height of nest-box placement & $4.3 \pm 0.76$ \\
\hline Holder type & Type of nest-box holder & pylon $(55.3 \%)$, tree $(44.7 \%)$ \\
\hline $\begin{array}{l}\text { Closest natural ter- } \\
\text { ritory }\end{array}$ & $\begin{array}{l}\text { Distance to the observation of } \\
\text { the closest natural breeder (m) }\end{array}$ & $14765 \pm 15463$ \\
\hline $\begin{array}{l}\text { Closest occupied } \\
\text { nest-box }\end{array}$ & $\begin{array}{l}\text { Distance to a closest occupied } \\
\text { nest-box in } 2010(\mathrm{~m})\end{array}$ & $5195 \pm 5088$ \\
\hline $\begin{array}{l}\text { Density of occupied } \\
\text { boxes }\end{array}$ & $\begin{array}{l}\text { Number of occupied boxes in } \\
10 \mathrm{~km} \text { range in } 2010\end{array}$ & $14.3 \pm 13.1$ \\
\hline Large arable fields & $\begin{array}{l}\text { Proportion (\%) of large arable } \\
\text { fields (CLC code: } 2111)\end{array}$ & $9.7 \pm 17.3$ \\
\hline Small arable fields & $\begin{array}{l}\text { Proportion (\%) of small arable } \\
\text { fields (CLC code: } 2112 \text { ) }\end{array}$ & $29.9 \pm 23.2$ \\
\hline Orchards & $\begin{array}{l}\text { Proportion (\%) of orchards } \\
\text { (CLC code: } 222 \text { ) }\end{array}$ & $0.56 \pm 2.1$ \\
\hline Grasslands & $\begin{array}{l}\text { Proportion }(\%) \text { of grasslands } \\
\text { (CLC code: } 231+321)\end{array}$ & $25.6 \pm 21.0$ \\
\hline Complex cultivation & $\begin{array}{l}\text { Proportion (\%) of complex cul- } \\
\text { tivation fields ( CLC code: } 242 \text { ) }\end{array}$ & $10.4 \pm 19.4$ \\
\hline
\end{tabular}

Cover 2006 program (Quantum GIS 1.8.0). The land cover types, which are considered as typical feeding sites for rollers, were included in the analyses such as grasslands, complex cultivation patterns, large and small arable fields and orchards (Table 1). The data of territory mapping and nest-box occupancy in 2010 were used to determine the initial roller population density in the area where the nest-boxes were installed. The number of all known breeding pairs within a $10 \mathrm{~km}$ radius around the nest-boxes was used for calculation (Table 1). The distance of nearest neighbours from the newly installed nest-boxes in 2010 was also calculated by using a GIS program (Quantum GIS 1.8.0).

\section{Statistical analysis}

We evaluated the effects of the environmental variables, nearby presence of rollers, and nest-box placement conditions (height above ground, holder type and orientation) on the occupancy rate of nest-boxes by linear models. Two main models were used: (i) the dependent variable was "ad-hoc occupancy", expressing the maximal potential usability of nest-boxes on the binary basis (occupied for at least once within the four-year study period). We used generalized linear model (binomial distribution with the logit link function) for revealing which factors and covariates are responsible for this preference for nest-box 
Table 2. Results of generalized linear models for the prolonged nest-box occupancy by European rollers. The best fit model is shown (a), where variables with the highest explanatory value were retained. (The dependent variable expresses if the nest-box was occupied in the whole monitoring period between 2011 and 2014 on the binary bases: Y/N; factors: orientation, height above ground and holder type of nest-box; covariates: height, grasslands, large and small arable fields, orchards, grasslands, complex and distance of closest potential natural breeder, distance of closest occupied nest-boxes, number of occupied boxes within $10 \mathrm{~km}$. See methods and Table 1 for more detailed explanations of the variables.) Parameter estimates for the best fit model is also shown (b).

\begin{tabular}{|c|c|c|c|c|c|}
\hline (a) The best fit model & \multicolumn{2}{|l|}{ Wald $\chi^{2}$} & $\mathrm{df}$ & \multicolumn{2}{|c|}{$\mathrm{p}$} \\
\hline Holder type & \multicolumn{2}{|l|}{11.596} & 1 & \multicolumn{2}{|c|}{0.01} \\
\hline Height above ground & \multicolumn{2}{|l|}{3.896} & 1 & \multicolumn{2}{|c|}{0.048} \\
\hline Closest natural territory & \multicolumn{2}{|l|}{14.234} & 1 & \multicolumn{2}{|c|}{$<0.001$} \\
\hline \multicolumn{6}{|c|}{$\begin{array}{l}\text { Model fitting: likelihood ratio } \chi^{2}=28.525, \mathrm{df}=3, \mathrm{p}<0.001, \mathrm{AIC}=134.167, \mathrm{AIC}_{\mathrm{FULL}}-\mathrm{AI}- \\
\mathrm{C}_{\mathrm{BEST}}=17.885\end{array}$} \\
\hline (b) Parameter estimates & B & se & Wald $\chi^{2}$ & df & $\mathrm{p}$ \\
\hline Holder type (pylon) & 1.744 & 0.512 & 11.598 & 1 & 0.01 \\
\hline Height above ground & 0.619 & 0.314 & 3.896 & 1 & 0.048 \\
\hline Closest natural territory & $-6.234 \mathrm{E}-5$ & $1.652 \mathrm{E}-4$ & 18.237 & 1 & $<0.001$ \\
\hline
\end{tabular}

occupancy. We ran variants of the model, from the full model which included all factors and variables toward the best fit model using the Akaike information criteria (AIC) for model selection (BURNHAM \& ANDERson 2002). (ii) We also used generalized linear model (multinomial distribution with the cumulative logit link function) to reveal how the former variables affect "frequency of occupancy" as the dependent variable. All analyses were done by the SPSS 22.0 software.

\section{RESULTS}

From the 132 newly provided nest-boxes 96 (72.7\%) were occupied at least once by rollers during the four-year study period. Thirty-nine nest-boxes (29.5\%) were occupied at the first time in 2011 (Fig. 2). Nineteen nest-boxes $(14.4 \%)$ were occupied in each of the years in the four-year study period, 31 nest-boxes (23.5\%) were occupied three times, 25 (18.9\%) twice and 25 (18.9\%) were used only once by rollers. A generalized linear model revealed which factors affected occupancy (yes/no) of the newly provided nest-boxes in the four-year study period, representing the preference for certain nest-boxes (Table 2). Consequently, $72.7 \%$ of the 132 nest-boxes were utilized for at least one year, and the rest $(27.3 \%)$ were never used by rollers in any of the four years of the study. Among the nest-box characteristics, holder type, i.e. the nestbox was placed on a pylon or in a tree, as well as the height of the nest-boxes above ground had significant effects on rollers'nest-box occupancy (Table 2). 
Interestingly, the presence of rollers potentially breeding in nearby natural breeding sites (closest natural territory) was also significant. However, we did not find any significant effect of land-cover compositon at the territory scale.

Another generalized linear model on the effects influencing nest-box occupancy within the four-year study period revealed similar results (Table 3). However, the second best fit model also showed that orientation of nest-boxes may also affect their occupancy, as the southward direction was not preferred by rollers $\left(\beta=-1.279\right.$, se $=0.595$, Wald $\left.c^{2}=4.611, d f=1, p=0.032\right)$. Frequency of typical feeding sites, such as grasslands and small arable lands, did not influence the frequency of occupancy. Considering the importance of the presence of conspecifics we found a slightly positive effect of the proximity of breeding pairs both for nest-boxes and potential natural breeding sites (Fig. 2 ), although the higher population density around $10 \mathrm{~km}$ of the nests seems to affect negatively the repeated usage of nest-boxes, but this result was not significant (Table 3b).

\section{DISCUSSION}

The correct placement of artificial nest-boxes may fundamentally affect the usefulness of a bird conservation program for cavity-nesters. Therefore nest-box provisioning should consider all factors influencing nest-site selection of a given species. We found that nest-box characteristics significantly affected subsequent occupancy rates by rollers. The same three factors have the most important effect both on occupancy (yes/no) and frequency of oc-

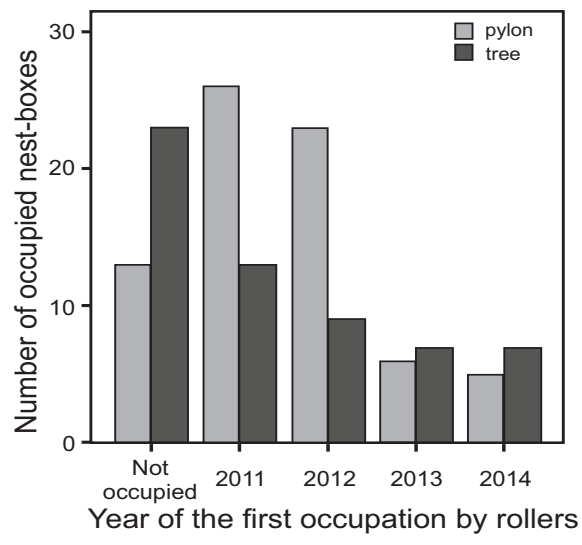

Fig. 2. Occupancy pattern of the newly provided nest-box during the study period

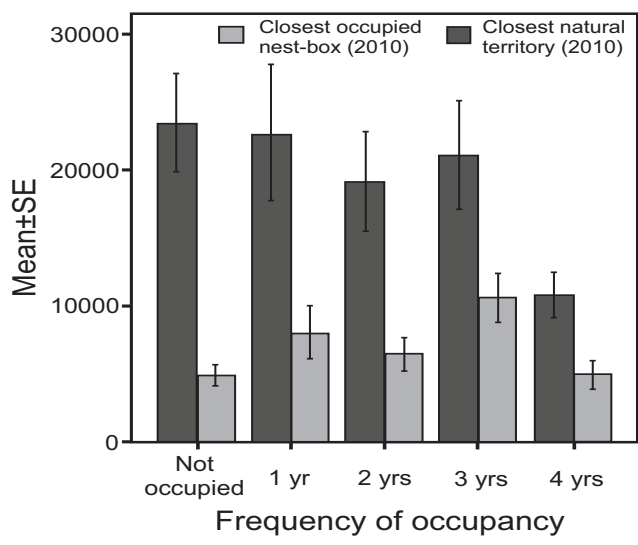

Fig. 3. The distance to the closest breeder in nest-box and potential natural breeding sites, as well as the length of occupancy of rollers in the four-year study period (horizontal axis) 
Table 3. Results of generalized linear models for the frequency of nest-box occupancy by rollers in a four-year study period. The best fit (a) and the second best fit (b) models are shown, where variables with the highest explanatory value were retained. The dependent variable expresses the frequency of occupancy during the 4-year study period; factors: orientation, holder type, height above ground; covariates: height, distance of closest potential natural breeder distance of closest occupied nest-boxes, number of occupied boxes within $10 \mathrm{~km}$, and land cover types in small and large arable fields, grasslands, orchards and complex cultivation patterns. Parameter estimates for the best fit model is also shown (c).

\begin{tabular}{lccc}
\hline (a) The best fit model & Wald $\chi^{2}$ & $\mathrm{df}$ & $\mathrm{p}$ \\
\hline Holder type & 16.192 & 1 & $<\mathbf{0 . 0 0 1}$ \\
Height above ground & 5.698 & 1 & $\mathbf{0 . 0 1 7}$ \\
Closest natural territory & 16.958 & 1 & $<\mathbf{0 . 0 0 1}$ \\
\hline
\end{tabular}

Model fitting: likelihood ratio $\chi^{2}=35.86, \mathrm{df}=3, \mathrm{P}<0.001, \mathrm{AIC}=395.581$, $\mathrm{AIC}_{\mathrm{FULL}}-\mathrm{AIC}_{\mathrm{BEST}}=9.705$

\begin{tabular}{|c|c|c|c|c|c|}
\hline (b) The second best fit model & Wald $\chi^{2}$ & $\mathrm{df}$ & \multicolumn{3}{|c|}{$\mathrm{p}$} \\
\hline Orientation & 10.379 & 7 & \multicolumn{3}{|c|}{0.168} \\
\hline Holder type & 19.572 & 1 & \multicolumn{3}{|c|}{$<0.001$} \\
\hline Height above ground & 3.847 & 1 & \multicolumn{3}{|c|}{0.05} \\
\hline Closest natural territory & 18.237 & 1 & \multicolumn{3}{|c|}{$<0.001$} \\
\hline Closest occupied nest-box & 3.698 & 1 & \multicolumn{3}{|c|}{0.054} \\
\hline Density of occupied boxes & 3.003 & 1 & \multicolumn{3}{|c|}{0.083} \\
\hline \multicolumn{6}{|c|}{$\begin{array}{l}\text { Model fitting: likelihood ratio } \chi^{2}=50.63, \mathrm{df}=12, \mathrm{P}<0.001, \mathrm{AIC}=398.804 \text {, } \\
\mathrm{AIC}_{\mathrm{FULL}}-\mathrm{AIC}_{\mathrm{BEST}}=6.482\end{array}$} \\
\hline $\begin{array}{l}\text { (c) Parameter estimates for the best } \\
\text { model }\end{array}$ & $B$ & se & Wald $\chi^{2}$ & $\mathrm{df}$ & $\mathrm{p}$ \\
\hline Holder type (pylon) & 1.416 & 0.352 & 16.192 & 1 & $<0.001$ \\
\hline Height above ground & 0.547 & 0.229 & 5.698 & 1 & 0.017 \\
\hline Closest natural territory & $-5.642 \mathrm{E}-5$ & $1.370 \mathrm{E}-5$ & 16.958 & 1 & $<0.001$ \\
\hline
\end{tabular}

cupancy in the four-year study period. These were the conspecific presence, height and holder type. Nest-site selection of birds may also be influenced by the presence of conspecifics already settled for breeding in the area (see e.g. Danchin et al. 2001). In the present study we investigated several factors concerning the significance of the presence of conspecifics. We found that the distance to the closest occupied nest-box or natural breeding hollow may affect nest-box occupancy. This finding supports the result of a Spanish study (VÁclav et al. 2011), which showed that conspecific social attraction was important to the colonization of nest-boxes in the same season. Our results high- 
light the significance of the presence of conspecifics from a conservation point of view. A preliminary survey of the local population before the starting of the nest-box provisioning program may increase its efficiency. However, we found that the closest natural breeders affected more occupancies than the closest pairs breeding in artificial nest-boxes.

Nest-box preference seems to be varying by region, probably reflecting to habitat structure, also including nearby feeding areas. In France, Bouvier et al. (2014) found that rollers breeding in natural hollows preferred lower natural holes (5.92 $\pm 0.41 \mathrm{~m}$, mean \pm s.d.), and ButLER (2001) found strong preference for cavities with either south-westward or north-westward entrance orientation. One study from Slovakia reported much higher average height of natural breeding holes occupied by rollers (ca. $11 \mathrm{~m}$ ) and the orientation was always toward open space suggesting the importance of direct flight paths from and into the cavities (BoHus 2002). In our study we found that rollers preferred nest-boxes located on pylons than those were placed on trees. RoDRIGUEZ et al. (2011) reported that rollers preferred more visible nest-boxes, however, pairs using these boxes showed lower breeding performance than others that occupied and bred in natural holes. Nest-boxes installed on electric pylons are more visible compared with nest-boxes placed on trees, where leaves normally serve as camouflage, therefore boxes should be placed with caution. However, Rodriguez et al. (2011) also found that rollers breeding in both exposed and concealed sites had similar individual quality and more frequent nest failures was explained by a higher risk of snake predation. The main predator in Spain was the Spanish Montpellier snake (Malpolon monspessulanus) (PAREjo \& Avilés 2011), but similar snake predators are absent from our study area.

Habitat selection of European rollers has already been investigated in several countries across Europe. In Austria rollers mainly use agricultural lands for foraging sites in the early breeding season, but they use fallows and grasslands from mid-summer (SACKL et al. 2004). In Spain rollers' breeding success suggested that woodland-free pastures were the most suitable habitats for this species, however, irrigated fields seem to be suboptimal (AvilÉs \& PAREjo 2004). In France fallows and meadows were the important favoured breeding sites (Bouvier et al. 2014). In this study we did not find any significant effect of the typical feeding sites on the frequency of nest-box occupancy at the territory scale. Contrary, former findings in Spain reported unfavourable agricultural intensification for rollers (Avilés \& Pajero 2004, Donald et al. 2006), and also for several grassland birds in Hungary (BATÁry et al. 2007). As the new nest-boxes were provided within the frame of a conservation program in our study, the primary goal was to supplement new nesting sites into suitable roller habitats, where proper feeding habitats were available 
for rollers. However, we should consider that CORINE land-cover may not provide sufficient data to characterize the neighbouring area of nest-boxes properly and the effects of potential feeding areas on occupancy rate require further investigation. BrambiLla (2009) showed that GIS-models may miss to identify important factors affecting species' occurrence. Although many farmland bird species and long distance migrants decreased recently in Hungary (SzÉP et al. 2012), the roller population seems to be affected primarily by the reduced availability of natural hollows used for breeding (Kovács et al. 2008). Consequently, nest-box supplementation proved to be a highly effective tool in the conservation of rollers in Hungary (Molnár 1998, Kiss et al. 2014), which stabilized the threatened and declining population in areas where landscape composition is favourable (Kiss et al. 2016) and high-quality feeding sites are available (Kiss et al. 2014). Other bird species in the same breeding habitat, such as the lesser grey shrike (Lanius minor), which typically breed in open-cup nests, seem to be more vulnerable (Lovíszi et al. 2000). Our results revealed which factors affect the efficiency of nest-box supplementation programs in southern Hungary. Our results also revealed the importance of correct placement of nest boxes (height, holder type and habitat), but preservation of suitable breeding habitat must be involved into the long-term conservation management of the European roller.

*

Acknowledgements - We are grateful to Tamás Kiss, Csaba Mészáros, Péter Szűcs, Erna Borbáth, Gábor Balogh and the volunteers of BirdLife Hungary for their assistance in the field. We are thankful for the Kiskunság National Park Directorate for their logistic support and field assistance. The research was supported by HU-SRB IPA CBC project (HU-SRB 0910/122/120). The Ministry of Agriculture (former Ministry of Environment and Water) provided permission for research.

\section{REFERENCES}

Avilés, J. M. \& SÁNCHEZ, A. (2000): Avian responses to nest-box installation in steppes of the south-west of the Iberian Peninsula (Extremadura). Avocetta 24: 51-54.

Avilés, J. M., SÁnchez, J. M. \& Parejo, D. (2000): Nest-site selection and breeding success in the roller (Coracias garrulus) in the southwest of the Iberian Peninsula. Journal of Ornithology 141: 345-350. https://doi.org/10.1017/S095927090400022X

Avilés, J. M. \& PArejo, D. (2004): Farming practices and roller Coracias garrulus conservation in south-west Spain. Bird Conservation International 14: 173-181. https://doi. org/10.1017/S095927090400022X

BAtÁRY, P., BÁLDI, A. \& ERdôs, S. (2007): Grassland versus non-grassland bird abundance and diversity in managed grasslands: local, landscape and regional scale effects. Biodiversity and Conservation 16: 871-881. https://doi.org/10.1007/s10531-006-9135-5

Boнus, M. (2002): On breeding biology of the roller (Coracias garrulus) in the Komárno town surroundings (SW Slovakia, Danubian Basin). Sylvia 38: 51-59. 
Bouvier, J. C., Muller, I., Génard, M., Lescourret, F. \& Lavigne, C. (2014): Nest-site and landscape characteristics affect the distribution of breeding pairs of European rollers Coracias garrulus in an agricultural area of southeastern France. Acta Ornithologica 49: 23-32. https://doi.org/10.3161/000164514X682869

Brambilla, M., Casale, F., Bergero, V., Crovetto, G. M., Falco, R., Negri, I., Siccardi, P. \& Bogliani, G. (2009): GIS-models work well, but are not enough: Habitat preferences of Lanius collurio at multiple levels and conservation implications. Biological Conservation 10: 2033-2042. https://doi.org/10.1016/j.biocon.2009.03.033

Burnham, K. P. \& Anderson, D. R. (2002): Model selection and multimodel inference. A practical information-theoretic approach. 2nd ed., Springer, New York, 488 pp.

Butler, S. J. (2001): Nest-site selection by the European roller (Coracias garrulus) in southern France. MSc Thesis, University of York, UK, 610 pp.

Cramp, S. (ed.) (1998): The complete birds of the western Palearctic on CD-ROM. Oxford University Press, Oxford.

Danchin, E., Heg, D. \& Doligez, B. (2001): Public information and breeding habitat selection. Pp. 243-258. In: Clobert, J., Danchin, E., Dhondt, A. A. \& Nichols, J. D. (eds): Dispersal. Oxford University Press, Oxford.

Donald, P. F., Sanderson, F. J., Burfield, I. J. \& Bommel, F. P. J. van (2006): Further evidence of continent-wide impacts of agricultural intensification on European farmland birds, 1990-2000. Agriculture, Ecosystems and Environment 116: 189-196. https:// doi.org/10.1016/j.agee.2006.02.007

Goodenough, A. E., Maitland, D. P, Hart, A. G. \& Elliot, S. L. (2008): Nestbox orientation: a species-specific influence on occupation and breeding success in woodland passerines. Bird Study 55: 222-232. https://doi.org/10.1080/00063650809461526

Gottschalk, T. K., Eкschmitт, K. \& Wolters, V. (2011): Efficient placemet of nest-box for the little owl (Athene noctua). Journal of Raptor Research 45: 1-14. https://doi. org/10.3356/JRR-09-11.1

HaraszThy, L. (ed.) (1984): Magyarország fészkelő madarai [Breeding birds of Hungary]. Natura, Budapest, 247 pp. [In Hungarian]

Johnsson, K., Nilsson, S. G. \& TJernberg, M. (1993): Characteristics and utilization of old black woodpecker Dryocopus martius holes by hole-nesting species. Ibis 135: 410416. https://doi.org/10.1111/j.1474-919X.1993.tb02113.x

Kiss, O. \& Tокору, B. (2010): A szalakóta (Coracias garrulus) helyzete és a védelmi intézkedések összefoglalása a Dél-Alföldön. (Roller population in southern Hungary.) Heliaca 8: 108-11. [In Hungarian]

Kiss, O., EleK, Z. \& Moskát, C. (2014): High breeding performance of European rollers Coracias garrulus in a heterogeneous farmland habitat of southern Hungary. Bird Study 61: 496-505. https://doi.org/10.1080/00063657.2014.969191

Kiss, O., Токорy, B., DeÁк, B. \& МоsкÁт, C. (2016): Increased landscape heterogeneity supports the conservation of European rollers (Coracias garrulus) in southern Hungary. Journal for Nature Conservation 29: 97-104. https://doi.org/10.1016/j.jnc.2015.12.003

Klein, Á., NAgY, T., Csörgő, T. \& Mátics, R. (2007): Exterior nest-boxes may negatively affect barn owl Tyto alba survival: an ecological trap. Bird Conservation International 17: 273-281. https://doi.org/10.1017/S0959270907000792

Kоврімӓкі, Е. (1985): Clutch size and breeding success in relation to nest-box size in Tengmalm's owl Aegolius funereus. Holarctic Ecology 8: 175-180. https://doi.org/ 10.1111/j.1600-0587.1985.tb01168.x 
Kovács, A., Barov, B., Orhun, C. \& Gallo-Orsi, U. (2008): International species action plan for the European roller Coracias garrulus garrulus. Available at: http://ec.europa.eu/ environment/nature/conservation/wildbirds/action_plans/docs/coracias_garrulus_ garrulus.pdf

Lambrechts, M., Wiebe, K., Sunde, P., Solonen, T., Sergio, F., Roulin, A., Moller, A. P., Lopez, B. C., Fargallo, J., Exo, K. M., Dell'Omo, G., Costantini, D., Charter, M., Butler, M., Bortolotti, G., Arlettaz, R. \& Korpimaki, E. (2012): Nest box design for the study of diurnal raptors and owls is still an overlooked point in ecological, evolutionary and conservation studies: a review. Journal of Ornithology 153: 23-34. https:// doi.org/10.1007/s10336-012-0919-y

Lopez, B. C., Potrony, D., Lopez, A., Badosa, E., Bonada, A. \& Salo, R. (2010): Nest-box use by boreal owl (Aegolius funereus) in Pyrenees mountains in Spain. Journal of Raptor Research 44: 40-49. https://doi.org/10.3356/JRR-09-32.1

Lovászi, P., BÁrtol, I. \& Moskát, C. (2000): Nest site selection and breeding success of the lesser grey shrike (Lanius minor) in Hungary. Ring 22: 157-164.

Lowther, P. E. (2012): Does nest-box size impact clutch size of house sparrows? Wilson Journal of Ornithology 124: 384-389. https://doi.org/10.1676/11-166.1

Magyar, G., Hadarics, T., Waliczky, Z., Schmidt, A., Nagy, T. \& Bankovics, A. (1998): Nomenclator Avium Hungariae. Hungarian Ornithological Institute, Budapest and Szeged, 202 pp.

Martin, K. \& EAdie, J. M. (1999): Nest webs: A community-wide approach to the management and conservation of cavity-nesting forest birds. Forest Ecology and Management 115: 243-257. https://doi.org/10.1016/S0378-1127(98)00403-4

Møller, A. P., Adriaensen, F., Artemyev, A., Banbura, J., Barba, E., Biard, C., Blondel, J., Bouslama, Z., Bouvier, J. C., Camprodon, J., Cecere, F., Chaine, A., Charmantier, A., Charter, M., Cichon, M., Cusimano, C., Czeszczewik, D., Doligez, B., Doutrelant, C., Dubiec, A., Eens, M., Eeva, T., Faivre, B., Ferns, P. N., Forsman, J. T., Garcia-del-Rey, E., Goldshtein, A., Goodenough, A. E., Gosler, A. G., Gozdz I., Gregoire, A., Gustafsson, L., Hartley, I. R., Heeb, P., Hinsley, S. A., Isenmann, P., Jacob, S., Jarvinen, A., Juskaitis, R., Kania, W., Korpimaki, E., Krams, I., Laaksonen, T., Leclerce, B., Lehikoinen, E., Loukola, O., Lundberg, A., Mainwaring, M. C., Mand, R., Massa, B., Mazgajski, T. D., Merino, S., Mitrus, C., Mönkkönen, M., Morales-Fernaz, J., Moreno, J., Morin, X., Nager, R. G., Nilsson, J. A., Nilsson, S. G., Norte, A. C., Orell, M., Perret, P., Perrins, C. M., Pimentel, C. S., Pinxten, R., Priedniece, I., Quidoz, M. C., Remes, V., Richner, H., Robles, H., Russell, A., Rytkönen, S., Senar, J. C. Seppanen, J. T. da Silva, L. P., Slagsvold, T., Solonen, T., Sorace, A., Stenning, M. J., TöröK, J., Tryjanowski, P., van Noordwijk, A. J., von Numers, M., Walankiewicz, W. \& Lambrechts, M. M. (2014): Clutch-size variation in Western Palaearctic secondary hole-nesting passerine birds in relation to nest box design. Methods in Ecology and Evolution 5: 353-362. https://doi.org/10.1111/2041210X.12160

Molnár, G. (1998): Breeding biology and foraging of rollers (Coracias garrulus) nesting in nest-boxes. Ornis Hungarica 8. Supplement 1: 119-124. [in Hungarian, with an English summary]

Navara, K. J. \& Anderson, E. M. (2011): Eastern bluebirds choose nest boxes based on box orientation. Southeastern Naturalist 10: 713-720. https://doi.org/10.1656/058.010.0410

Newton, I. (1994): The role of nest sites in limiting the numbers of hole-nesting birds: a review. Biological Conservation 70: 265-276. https://doi.org/10.1016/0006-3207(94)90172-4 
Olah, G., Vigo, G., Heinsohna, R. \& Brightsmith, D. J. (2014): Nest site selection and efficacy of artificial nests for breeding successof scarlet macaws Ara macao macao in lowland Peru. Journal for Nature Conservation 22: 176-185. https://oi.org/10.1016/j. jnc.2013.11.003

Parejo, D., Danchin, E. \& Avilés, J. M. (2004): The heterospecific habitat copying hypothesis: can competitors indicate habitat quality? Behavioral Ecology 16: 96-105. https:// doi.org/10.1093/beheco/arh136

Parejo, D. \& Avilés, J. M. (2011): Predation risk determines breeding territory choice in a Mediterranean cavity-nesting bird community. Oecologia 165: 185-191. https://doi. org/10.1007/s00442-010-1723-0

Remacha, C. \& Delgado, J. A. (2009): Spatial nest-box selection of cavity-nesting bird species in response to proximity to recreational infrastructures. Landscape and Urban Planning 93: 46-53. https://doi.org/10.1016/j.landurbplan.2009.06.004

Rodriguez, J., Avilés, J. M. \& Parejo, D. (2011): The value of nestboxes in the conservation of Eurasian rollers Coracias garrulus in southern Spain. Ibis 153: 735-745. https://doi. org/10.1111/j.1474-919X.2011.01161.x

Sackl, P., Tiefenbach, M., Ilzer, W., Pfeiler, J. \& Wieser, B. (2004): Monitoring the Austrian relict population of European roller Coracias garrulus - a review of preliminary data and conservation implications. Acrocephalus 121: 51-57.

Sosnowski, J. \& Chmielewski, S. (1996): Breeding biology of the roller Coracias garrulus in Puszcza Pilicka Forest (Central Poland). Acta Ornithogica 31: 119-131.

Szép, T., NAgY, K., NagY, Z. \& Halmos, G. (2012): Population trends of common breeding and wintering birds in Hungary, decline of long distance migrant and farmland birds during 1999-2012. Ornis Hungarica 20: 13-63. https://doi.org/10.2478/orhu-2013-0007

SziJj, J. (1958): Beiträge zur Nahrungsbiologie der Blauracke in Ungarn. Bonn Zoological Bulletin 9: 25-39.

Sutherland, W. J., Newton, I. \& Green, R. E. (2004): Bird ecology and conservation. Oxford University Press, New York, 404 pp. https://doi.org/10.1093/acprof:oso/978019852 0863. 001.0001

Tome, R., Bloise, C. \& Korpimaki, E. (2004): Nest-site selection and nesting success of little owls (Athene noctua) in Mediterranean woodland and open habitats. Journal of Raptor Research 38: 35-46.

VÁclav, R., VAlera, F. \& MartinÉz, T. (2011): Social information in nest colonisation and occupancy in a long-lived, solitary breeding bird. Oecologia 165: 617-627. https://doi. org/10.1007/s00442-010-1848-1

Virkkala, R., Luoto, M. \& Rainio, K. (2004): Effects of landscape composition on farmland and red-listed birds in boreal agricultural-forest mosaics. Ecography 27: 273-284. https://doi.org/10.1111/j.0906-7590.2004.03810.x

WARD, M. P. \& SChlossberg, S. (2004): Conspecific attraction and the conservation of territorial songbirds. Conservation Biology 18: 519-525. https://doi.org/10.1111/j.15231739.2004.00494.x

Received December 14, 2015, accepted May 14, 2016, published March 3, 2017 


\title{
Contributions to a Manual of Palaearctic Diptera
}

\author{
Edited by L. Papp and B. Darvas
}

\section{Volumes 1-3, Appendix}

The excellently illustrated volumes of the "Contributions to a Manual of Palaearctic Diptera" morphological, physiological, genetical, ecological and economic up-to-date knowledge of dipterous species (midges and flies), which have significant importance in genetics as model organisms, in plant cultivation as pests or beneficial parasitoids, in animal husbandry and human health as vectors of serious illnesses and which are important for ecosystem function, are treated. Morphological keys to generic level for adults and larvae are provided, which help readers with identification of dipterous pests and parasitoids, while readers in the field of applied dipterology will find suitable environmentally friendly methods against pests or biological control methods.

Volume 1 (published in 2000): 24 chapters of general and applied dipterology, by 31 specialists, on 978 pages with 956 figures on 176 plates.

Volume 2 (published in 1997): 38 dipterous family chapters, by 23 specialists, on 592 pages with 1895 figures on 258 plates. Volume 3 (published in 1998): 56 dipterous family chapters, by 32 specialists, on 880 pages with 1773 figures on 294 plates. Appendix (published in 2000): 16 dipterous family chapters, by 19 specialists, on 604 pages with 2134 figures on 207 plates.

\author{
ISBN 9630488361 (Series) \\ ISBN 9630488396 (Volume 1) \\ ISBN $963048837 \mathrm{X}$ (Volume 2) \\ ISBN 9630488388 (Volume 3) \\ ISBN $963048840 \mathrm{X}$ (Appendix) $<\mathrm{R}>$ \\ Publisher: Science Herald, Budapest \\ Order should be sent to \\ NEST Foundation, Budapest \\ E-mail: planta@ludens.elte.hu
}

